Annals of Warsaw University of Life Sciences - SGGW

Land Reclamation No 40, 2008: 15-25

(Ann. Warsaw Univ. of Life Sci. - SGGW, Land Reclam. 40, 2008)

\title{
Changes of nutrient concentrations in water sensitive to nitrate pollution from agricultural sources in the Samica Stęszewska river catchment
}

\author{
AGNIESZKA E. ŁAWNICZAK, JANINA ZBIERSKA, JERZY KUPIEC \\ Department of Ecology and Environmental Protection University of Life Sciences in Poznań
}

\begin{abstract}
Changes of nutrient concentrations in water sensitive to nitrate pollution from agricultural sources in the Samica Stęszewska river catchment. The aim of this study was to evaluate the surface water quality during the first period of measures undertaken to reduce nitrate concentrations in the nitrate vulnerable zone. The study was carried out in the upper part of the Samica Stęszewska catchment, located in the Wielkopolska region (western Poland), designated by the nitrate directive as a nitrate vulnerable zone (Nitrate Directive 91/676/EC). Water samples were taken at nine control points from February 2003 to December 2007. The results indicate that nitrate pollution reduction measures taken in the nitrate vulnerable zones were ineffective in reducing this type of pollution. Water quality was poor at almost all of the monitoring points, and based on nitrate concentrations, water quality was classified in classes IV or V. The only exception was in the outflow from Lake Niepruszewskie, where water quality was classified as either class I, II or III. Also water quality in Lake Niepruszewskie was extremely eutrophic. Our results indicated a role of Lake Niepruszewskie as a nutrient sink reducing pollution from the catchment.
\end{abstract}

Key words: nitrate concentrations, agricultural pollution, surface water, nitrate directive.

\section{INTRODUCTION}

Measures taken to reduce nitrate water pollution from agricultural sources, particularly in Nitrate Vulnerable Zones $(\mathrm{NVZs})$, are being implemented in Poland in accordance with the nitrates directive (91/676/EC). In the Wielkopolska region, where fertilizer use is very high $\left(66.9 \mathrm{~kg} \mathrm{~N} \cdot \mathrm{ha}^{-1}, 20.5 \mathrm{~kg} \mathrm{P}_{2} \mathrm{O}_{5} \mathrm{ha}^{-1}\right.$, $26.4 \mathrm{~kg} \mathrm{~K}_{2} \mathrm{O} \mathrm{ha}^{-1}$, Rocznik... 2005) and animal production intense, $728.7 \mathrm{~km}^{2}$ were designated as nitrate vulnerable zones (NVZs) (Dz. Urz. Woj. Wlkp. nr 192, 2003). A wide range of measures available for reducing nitrate losses to groundwaters and surface waters has been applied including those associated with different soil management, fertilizer application, manure, livestock, and crop management, land use change, and combinations of such measures (DEFRA 2007a). Furthermore, the applicability and effectiveness of these measures varies with the employed farming system, climate and soil type.

Under the EC Nitrates Directive $(91 / 676)$, at least every four years the undertaken measures and NVZ areas must be reviewed (Rozporządzenie... 2002a). If the applied NVZ Action Programmes are not effective at reducing nitrate pollution or do not otherwise meet the Directive requirements, they are revised. As indicated by some studies, in many areas nitrate concentrations in water in the NVZs still remain high, despite reductions achieved by the current NVZ Action Programme (DEFRA 2006b, 
c; Report... 2007). Mostly, it refers to arable systems where the reduction of nitrate concentrations is more problematical due to a limit as to how far nitrate concentrations can be reduced for sufficient crop production even under combinations of measures. Although in some NVZ areas in England water quality is still poor (nitrate concentrations still exceed $50 \mathrm{mg} \mathrm{NO} \cdot \mathrm{dm}^{-3}$ ) indicating that the applied measures were not sufficiently effective (Hughes et al. 2006; Report... 2007), in most areas nitrate concentrations stabilised in recent years or slightly declining trends were observed. As indicated by research of other European countries where the nitrate directive is applied, four years is too short a time to achieve significant improvement of water quality in all NVZs (Report... 2007).

The aim of this study was to evaluate the surface water quality during the first period of actions undertaken to reduce nitrate concentrations in one of the designated nitrate vulnerable zone.

Research was carried out in one part of the designated nitrate vulnerable zones, namely in the upper part of the Samica Stęszewska catchment and included the Lake Niepruszewskie basin (western Poland). Surface water vulnerable to nitrogen pollution in this zone comprises: the $11.8 \mathrm{~km}$ section of the Samica Stęszewska river, from its source to Lake Niepruszewskie and Lake Niepruszewskie itself.

\section{SITE DESCRIPTION}

The Samica Steszewska river is a left bank tributary of the Kanał Mosiński (a left tributary of the Warta river). The total length of the river is $37.87 \mathrm{~km}$. The basin of the Samica Stęszewska river lies in the Wielkopolska Lowland in the region of the Wysoczyzna Poznańska (Kondracki 2001). The source of the river is to the southeast of the village of Ceradz Kościelny located in the Duszniki commune. The entire surface area of the catchment is $168.05 \mathrm{~km}^{2}$, while that addressed by the current study up to the outflow of Lake Niepruszewskie comprises $25.93 \mathrm{~km}^{2}$ (Czarnecka 2005). The river flows into Lake Niepruszewskie $28.5 \mathrm{~km}$ from its source; this lake is the largest one associated with this river, which links this lake with three others. The studied area contains seven streams that flow into the lake. Three of them are seasonal streams and only in two, water flows throughout the year (Fig. 1).

The nitrate vulnerable zone is an agricultural area that is typical of the Wielkopolska region (Zbierska et al. 2002). The land in the analyzed basin is used primarily for agriculture: arable land $-79.6 \%$; urban areas $-6.4 \%$; water bodies $-5.2 \%$ and grasslands $-2.1 \%$. Forest covers barely $6.8 \%$ of the upper part of the Samica Stęszewska basin. Crop production on the farms is rather simple, with most growing grains (53.9\% of arable land). The second type of production is based on industrial plants, mostly oil seed plants $(20.8 \%$ of arable land) and fodder root crops (13.6\% with sugar beets predominant). Maize production located within the lake catchment area is disadvantageous as it accelerates nutrient leaching to surface waters and groundwaters (Zbierska et al. 2002; Ławniczak and Zbierska 2007). This process is supported by the 


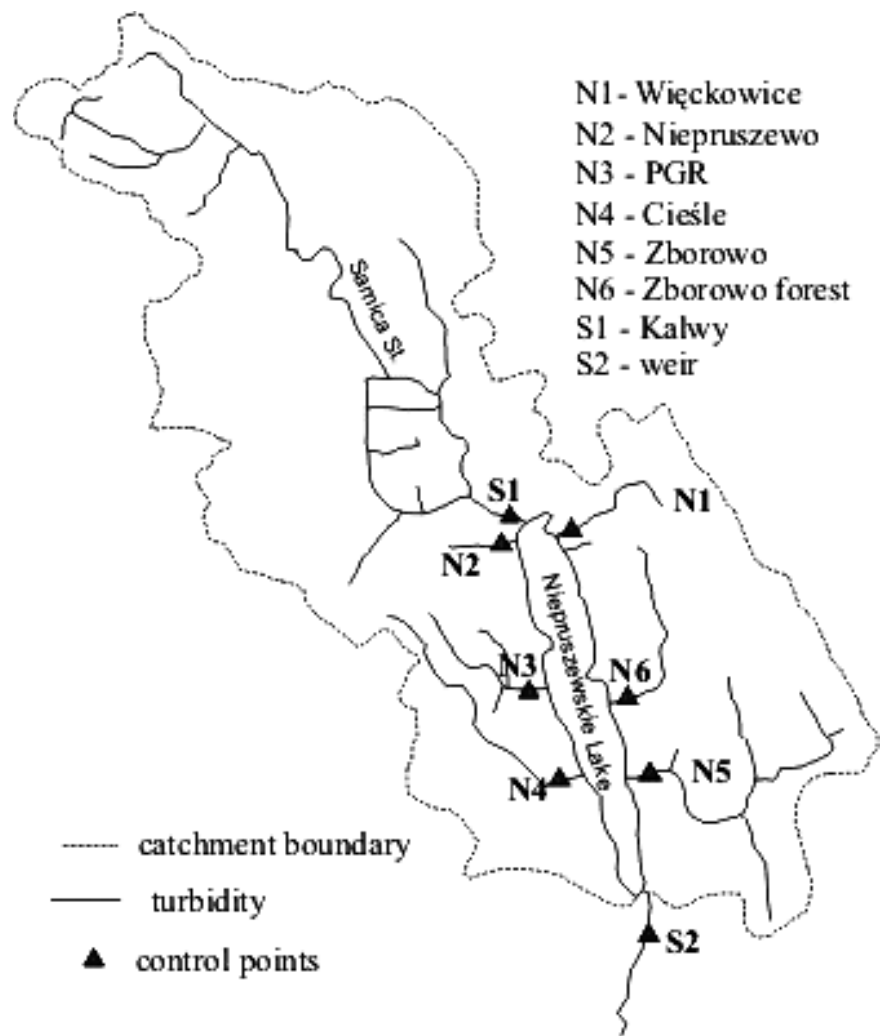

FIGURE 1. Location of the streams and river control points in the nitrate vulnerable zone of the upper part of the Samica Stęszewska catchment

substantial field slope in the catchment towards the lake and streams and a very high level of crop fertilization which is estimated at about $124 \mathrm{~kg} \mathrm{~N} \cdot \mathrm{ha}^{-1}, 25 \mathrm{~kg}$ $\mathrm{P}_{2} \mathrm{O}_{5} \cdot \mathrm{ha}^{-1}$, and $49 \mathrm{~kg} \mathrm{~K}_{2} \mathrm{O} \cdot \mathrm{ha}^{-1}$ (Kupiec 2008).

\section{MATERIAL AND METHODS}

The study was carried out from February 2005 to December 2007 at nine stations (Fig. 1). Two sites were located at the inflow (S1) and outflow (S2) of the Samica Stęszewska river into and out of Lake Niepruszewskie, six monitoring points were selected at the turbidities of Lake Niepruszewskie and one in the lake (Fig. 1). Samples of lake water were taken at the deepest point of the lake at depths of $0.5 \mathrm{~m}$ below the water surface. Water was sampled monthly. Nitrate (cadmium reduction method) and total phosphorus (acid persulfate digestion method) were analyzed with spectrophotometry (HACH 2400) in the laboratory of the Department of Ecology and Environmental Protection, University of Life Sciences in Poznan, within 6 hours of sampling. Chlorophyll $a$ content was measured colorimetrically in the AQUANET Water Laboratory in Poznań. Regular monitoring of surface water in the Samica Stęszewska river 
catchment enables the assessment of water quality against directive criteria for designating NVZs (Rozporządzenie... 2002b). Measured water quality parameters were referred to the Polish water pollution control regulation (Rozporządzenie... 2004) which is based on the 90th percentile value (for samples taken every months during the year) or the worst value (for periodic streams) refers to the water quality class.

All statistical analyses were performed with Statistica 7.1. The data were logtransformed to assess the homogeneity of variance. One-way and two-way interactions of the sampling data and nutrient concentrations were tested with analyses of variance (ANOVA). In all cases, a posteriori Bonferroni tests were performed.

\section{RESULTS}

Nitrate concentrations varied among the points surveyed $(\mathrm{F}=15.9 ; \mathrm{p}<0.000)$ and the years $(F=6.74 ; p=0.001)$. The highest nitrate concentration was observed at the inflow of the Samica Stęszewska River (S1) into that lake and in the three small streams (control sites N2, N5, N6; Tab. 1). In 2005 , nitrate concentrations in the water of the periodic stream N6 control point was statistically higher than at almost all the studied sites ( $\mathrm{F}=4.441$; $\mathrm{p}=0.001)$ except at the two small streams at sites N2 and N5. The highest values and greatest variability were observed in spring 2006 (Tab. 1). The nitrate concentrations at almost all of the control sites were higher than the limit for nitrate vulnerable zones (in excess of $50 \mathrm{mg} \mathrm{NO} \cdot \mathrm{Nm}^{-3}$ ). At two sites the concentration was as high as four times in excess of the allowable value $\left(\mathrm{N} 2-268.26 \mathrm{mg} \mathrm{NO} \mathrm{NO}_{3} \cdot \mathrm{dm}^{-3}\right.$, N5 $-238.16 \mathrm{mg} \mathrm{NO}_{3} \cdot \mathrm{dm}^{-3}$ ). Only the water at the inflow and outflow of the Samica Stęszewska River into and out of Lake Niepruszewskie and the small stream (N4) contained nitrate concentrations lowerthan $50 \mathrm{mg} \mathrm{NO}_{3} \cdot \mathrm{dm}^{-3}$. In 2007, high values were also recorded particularly in the spring. The highest variability occurred in the seasonal streams, where water was present only periodically. Except in the last year of the study, in the spring time, the inflow of the Samica Stęszewska river had the significantly highest nitrate concentrations of all of the analyzed water bodies $(\mathrm{F}=13.25, \mathrm{p}<$ $<0.000$ ). Thelowestnitrateconcentrations were recorded in the Samica Stęszewska river outflow from Lake Niepruszewskie at a range of 0.00 to $14.17 \mathrm{mg} \mathrm{NO} \cdot \mathrm{dm}^{-3}$ in the studied years (Tab. 1).

Total phosphorus concentrations in the analyzed surface waters were high and were indicative of eutrophic water (Tab. 2). Statistical differences were noted among the tested sites and among the years of the study ( $\mathrm{F}=2.729$, $\mathrm{p}<0.01)$. During the studied period, phosphorus content was below 0.25 $\mathrm{mg} \mathrm{P} \cdot \mathrm{dm}^{-3}$ at a range of 0.03 to 0.22 $\mathrm{mg} \mathrm{P} \cdot \mathrm{dm}^{-3}$ only in stream N1 (Tab. 2). The highest variation and extremely high $\mathrm{P}$ concentrations were noted in the streams located next to the villages of Niepruszewo and Zborowo. These high standard deviations appear to have been due to extremely high phosphorus concentrations during the fall, which were as high as $7.83 \mathrm{mg} \mathrm{P} \cdot \mathrm{dm}^{-3}$. In 2005 , the water in stream N3 showed increased P concentrations $\left(0.79 \mathrm{mg} \mathrm{P} \cdot \mathrm{dm}^{-3} \pm 0.17\right)$. 
TABLE 1. Nitrate concentrations $\left(\mathrm{mg} \mathrm{NO}_{3} \cdot \mathrm{dm}^{-3}\right)$ in the water bodies of the upper part of the Samica Stęszewska catchment in the 2005-2007

\begin{tabular}{|c|c|c|c|c|c|c|c|c|c|}
\hline \multirow{3}{*}{$\begin{array}{l}\vec{\Xi} \\
0 \\
0 \\
0 \\
0 \\
0 \\
0\end{array}$} & \multicolumn{3}{|c|}{2005} & \multicolumn{3}{|c|}{2006} & \multicolumn{3}{|c|}{2007} \\
\hline & Mean & Min. & $\begin{array}{c}90 \text { per. }{ }^{1} \\
\text { or the } \\
\text { worst } \\
\text { value }^{*}\end{array}$ & Mean & Min. & $\begin{array}{l}90 \text { per. } \\
\text { or the } \\
\text { worst } \\
\text { value }\end{array}$ & Mean & Min. & $\begin{array}{l}90 \text { per. } \\
\text { or the } \\
\text { worst } \\
\text { value }\end{array}$ \\
\hline & $\mathrm{SD}^{2}$ & Max & $\begin{array}{l}\text { Quality } \\
\text { class }^{3}\end{array}$ & SD & Max. & $\begin{array}{l}\text { Quality } \\
\text { class }\end{array}$ & SD & Max. & $\begin{array}{l}\text { Quality } \\
\text { class }\end{array}$ \\
\hline \multirow[t]{2}{*}{ S1 } & 41.95 & 0.80 & $90.31^{*}$ & 19.22 & 0.89 & $45.15^{*}$ & 31.33 & 6.64 & 43.83 \\
\hline & 33.58 & 90.31 & V & 16.76 & 45.15 & IV & 21.69 & 85.44 & IV \\
\hline \multirow[t]{2}{*}{ S2 } & 3.45 & 0.00 & 8.85 & 0.77 & 0.00 & 1.46 & 3.53 & 0.00 & 12.40 \\
\hline & 4.12 & 11.07 & II & 1.09 & 3.98 & I & 5.23 & 14.17 & III \\
\hline \multirow[t]{2}{*}{ N1 } & 31.87 & 14.17 & $52.68^{*}$ & 35.32 & 0.40 & $119.97^{*}$ & 28.84 & 8.85 & $42.10^{*}$ \\
\hline & 15.86 & 52.68 & V & 48.52 & 119.97 & V & 10.63 & 42.10 & IV \\
\hline \multirow[t]{2}{*}{ N2 } & 27.52 & 0.00 & 71.67 & 54.75 & 0.00 & 217.27 & 35.29 & 1.30 & 78.40 \\
\hline & 33.50 & 87.21 & V & 95.43 & 268.26 & V & 28.73 & 80.10 & V \\
\hline \multirow[t]{2}{*}{ N3 } & 43.10 & 8.41 & 66.40 & 22.58 & 0.40 & $87.65^{*}$ & 26.01 & 13.70 & 36.57 \\
\hline & 27.49 & 105.80 & V & 25.19 & 87.65 & V & 9.14 & 42.90 & IV \\
\hline \multirow[t]{2}{*}{ N4 } & 36.02 & 8.41 & 58.43 & 14.08 & 0.53 & 28.29 & 29.56 & 12.40 & 41.20 \\
\hline & 20.77 & 77.91 & V & 11.29 & 30.54 & IV & 9.10 & 41.60 & IV \\
\hline \multirow[t]{2}{*}{ N5 } & 42.20 & 15.94 & $74.81^{*}$ & 49.33 & 1.20 & $130.59^{*}$ & 57.85 & 25.68 & $113.30^{*}$ \\
\hline & 29.95 & $74 ., 81$ & V & 56.48 & 130.59 & V & 31.78 & 113.30 & V \\
\hline \multirow[t]{2}{*}{ N6 } & 44.52 & 13.72 & $82.34^{*}$ & 59.37 & 0.00 & $238.16^{*}$ & 40.23 & 9.50 & $106.20^{*}$ \\
\hline & 23.96 & 82.34 & V & 81.40 & 238.16 & $\mathrm{~V}$ & 35.50 & 106.20 & $\mathrm{~V}$ \\
\hline
\end{tabular}

${ }^{1} 90$ per. -90 percentyl, ${ }^{2} \mathrm{SD}$ - Standard deviations.

* Water quality estimate on the worst value for the periodic streams; bold - indicates values higher than $50 \mathrm{mg} \mathrm{NO} \cdot \mathrm{dm}^{-3}$.

Although water quality has improved significantly in recent years $(\mathrm{F}=17.571$, $\mathrm{p}<0.000)$, this has not been noted in streams N2 and N6, where increases of $\mathrm{P}$ concentrations in the water have been observed. However, the above increase was not statistically significant.

High total phosphorus concentrations and intense algal blooms indicated that the water quality of Lake Niepruszewskie was hypertrophic (Figs 2, 3). However, nitrate concentrations in the reservoir were low during all the vegetation seasons (V-IX, Fig. 4). Extremely high contents were observed in March 2007 $\left(25.52 \mathrm{mg} \mathrm{NO} \cdot \mathrm{dm}^{-3}\right)$. Total phosphorus concentrations were also high, particularly in the first year of the study (Fig. 2). Although, during the spring, concentrations gradually decreased due to intensive algal blooms, they still exceeded $0.1 \mathrm{mg} \mathrm{P} \cdot \mathrm{dm}^{-3}$ (indicative value for eutrophic water according the nitrate directive) during the studied 
TABLE 2. Total phosphorus concentrations $\left(\mathrm{mg} \mathrm{P} \cdot \mathrm{dm}^{-3}\right)$ in the water bodies of the upper part of the Samica Stęszewska catchment in the 2005-2007

\begin{tabular}{|c|c|c|c|c|c|c|c|c|c|}
\hline \multirow{3}{*}{ 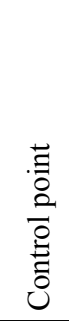 } & \multicolumn{3}{|c|}{2005} & \multicolumn{3}{|c|}{2006} & \multicolumn{3}{|c|}{2007} \\
\hline & Mean & Min. & $\begin{array}{l}90 \text { per. } \\
\text { or the } \\
\text { worst } \\
\text { value }^{*}\end{array}$ & Mean & Min. & $\begin{array}{l}90 \text { per. } \\
\text { or the } \\
\text { worst } \\
\text { value }\end{array}$ & Mean & Min. & $\begin{array}{l}90 \text { per. } \\
\text { or the } \\
\text { worst } \\
\text { value }\end{array}$ \\
\hline & $\mathrm{SD}^{2}$ & Max & $\begin{array}{l}\text { Quality } \\
\text { class }^{3}\end{array}$ & SD & Max. & $\begin{array}{c}\text { Quality } \\
\text { class }\end{array}$ & $\mathrm{SD}$ & Max. & $\begin{array}{c}\text { Quality } \\
\text { class }\end{array}$ \\
\hline \multirow[t]{2}{*}{ S1 } & 0.25 & 0.05 & $0.55^{*}$ & 0.20 & 0.10 & $0.37^{*}$ & 0.14 & 0.05 & 0.20 \\
\hline & 0.17 & 0.55 & III & 0.11 & 0.37 & II & 0.06 & 0.24 & I \\
\hline \multirow[t]{2}{*}{$\mathrm{S} 2$} & 0.13 & 0.07 & 0.20 & 0.16 & 0.05 & 0.20 & 0.11 & 0.07 & 0.12 \\
\hline & 0.05 & 0.22 & I & 0.10 & 0.45 & I & 0.04 & 0.22 & I \\
\hline \multirow[t]{2}{*}{ N1 } & 0.08 & 0.03 & $0.15^{*}$ & 0.12 & 0.07 & $0.11^{*}$ & 0.11 & 0.05 & $0.20^{*}$ \\
\hline & 0.05 & 0.15 & I & 0.06 & 0.22 & I & 0.05 & 0.20 & I \\
\hline \multirow[t]{2}{*}{$\mathrm{N} 2$} & 0.31 & 0.05 & 0.69 & 0.64 & 0.12 & 1.54 & 1.13 & 0.06 & 2.12 \\
\hline & 0.23 & 0.71 & III & 0.63 & 2.09 & V & 2.31 & 7.83 & V \\
\hline \multirow[t]{2}{*}{ N3 } & 0.79 & 0.35 & 1.14 & $\mathbf{0 . 3 3}$ & 0.15 & 0.56 & 0.23 & 0.05 & 0.33 \\
\hline & 0.34 & 1.42 & V & 0.22 & 0.91 & III & 0.11 & 0.45 & II \\
\hline \multirow[t]{2}{*}{ N4 } & 0.23 & 0.07 & 0.41 & 0.25 & 0.07 & 0.57 & 0.16 & 0.04 & 0.28 \\
\hline & 0.14 & 0.46 & III & 0.24 & 0.85 & III & 0.11 & 0.46 & II \\
\hline \multirow[t]{2}{*}{ N5 } & 0.29 & 0.09 & $0.41^{*}$ & 0.57 & 0.39 & $0.82^{*}$ & 0.57 & 0.22 & $1.40^{*}$ \\
\hline & 0.17 & 0.41 & III & 0.18 & 0.82 & IV & 0.41 & 1.40 & V \\
\hline \multirow[t]{2}{*}{ N6 } & 0.15 & 0.04 & $0.50^{*}$ & 0.62 & 0.09 & $1.93^{*}$ & 0.53 & 0.07 & $1.86^{*}$ \\
\hline & 0.19 & 0.50 & III & 0.70 & 1.93 & V & 0.59 & 1.86 & $\mathrm{~V}$ \\
\hline
\end{tabular}

${ }^{1} 90$ per. -90 percentyl, ${ }^{2} \mathrm{SD}-$ Standard deviations,

${ }^{*}$ water quality estimate on the worst value for the periodic streams; bold -values higher than $0.1 \mathrm{mg}$ $\mathrm{P} \cdot \mathrm{dm}^{-3}$.

period. Extremely high chlorophyll $a$ concentrations in the lake were observed from April to June 2005, but during the rest of the time, chlorophyll $a$ content still was very high (more than $25 \mu \mathrm{g}$. $\cdot \mathrm{dm}^{-3}$; Fig. 3).

\section{DISCUSSION}

The current results indicate that the preventative measures applied in nitrate vulnerable zones (Kupiec et al. 2008) were not effective enough to reduce nitrate pollution. Water quality was poor at nearly all the control points. Based on the nitrate concentrations, water quality was classified as IV or V. The only exception was at the outflow from Lake Niepruszewskie, where water quality was classified from classes I to III. Only water quality of the Samica Stęszewska river improved in comparison with the results from 1999-2002 (Zbierska et al. 2002). Moreover, water quality in the 


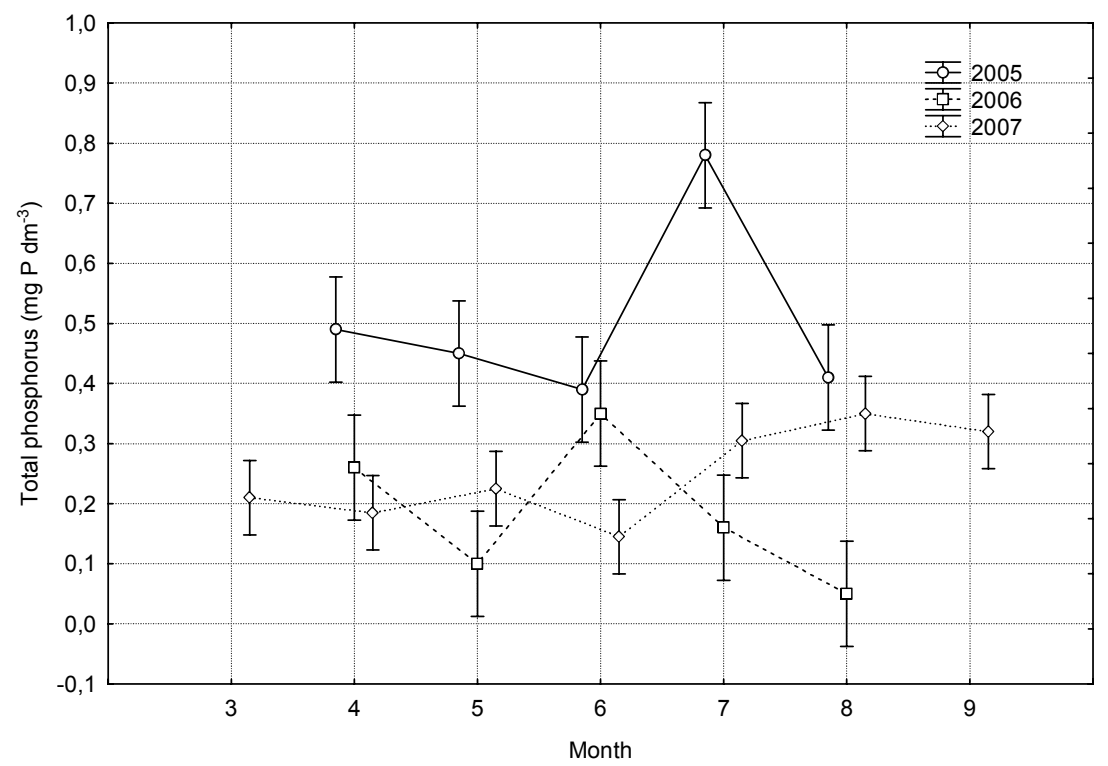

FIGURE 2. Total phosphorus concentrations $\left(\mathrm{mg} \mathrm{P} \cdot \mathrm{dm}^{-3}\right)$ in the Niepruszewskie Lake in the 2005-2007

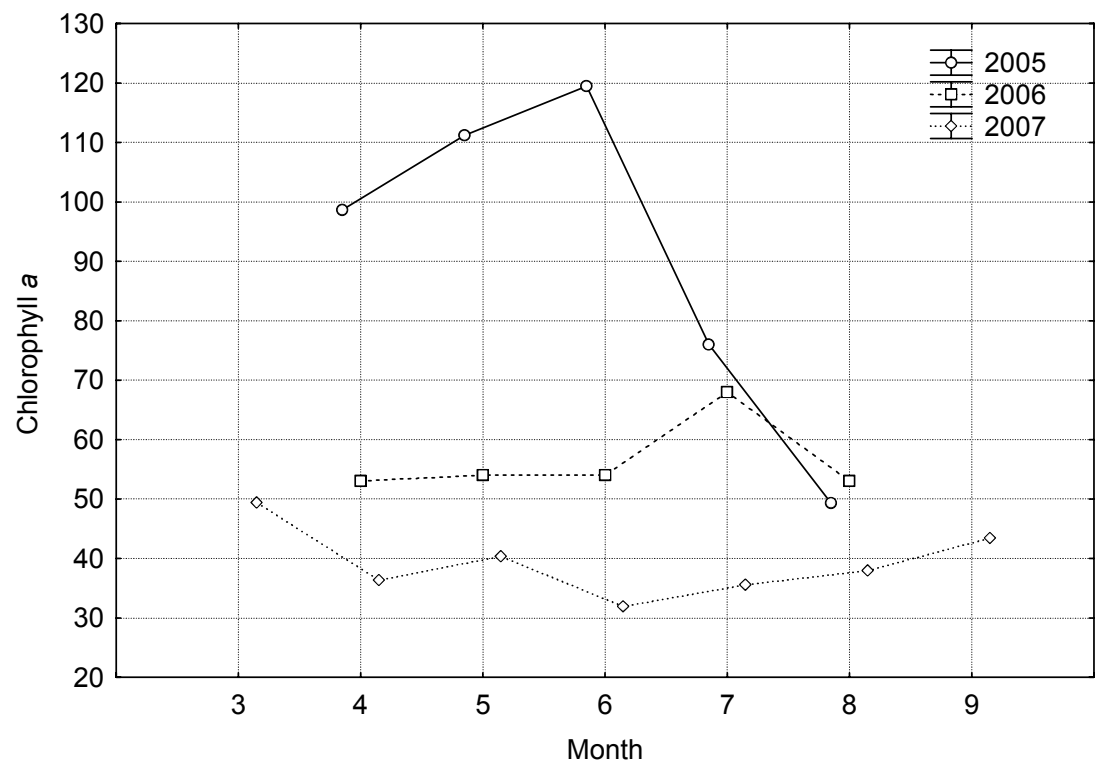

FIGURE 3. Chlorophyll a concentrations $\left(\mu \mathrm{g} \cdot \mathrm{dm}^{-3}\right)$ in the Niepruszewskie Lake in the 2005-2007 


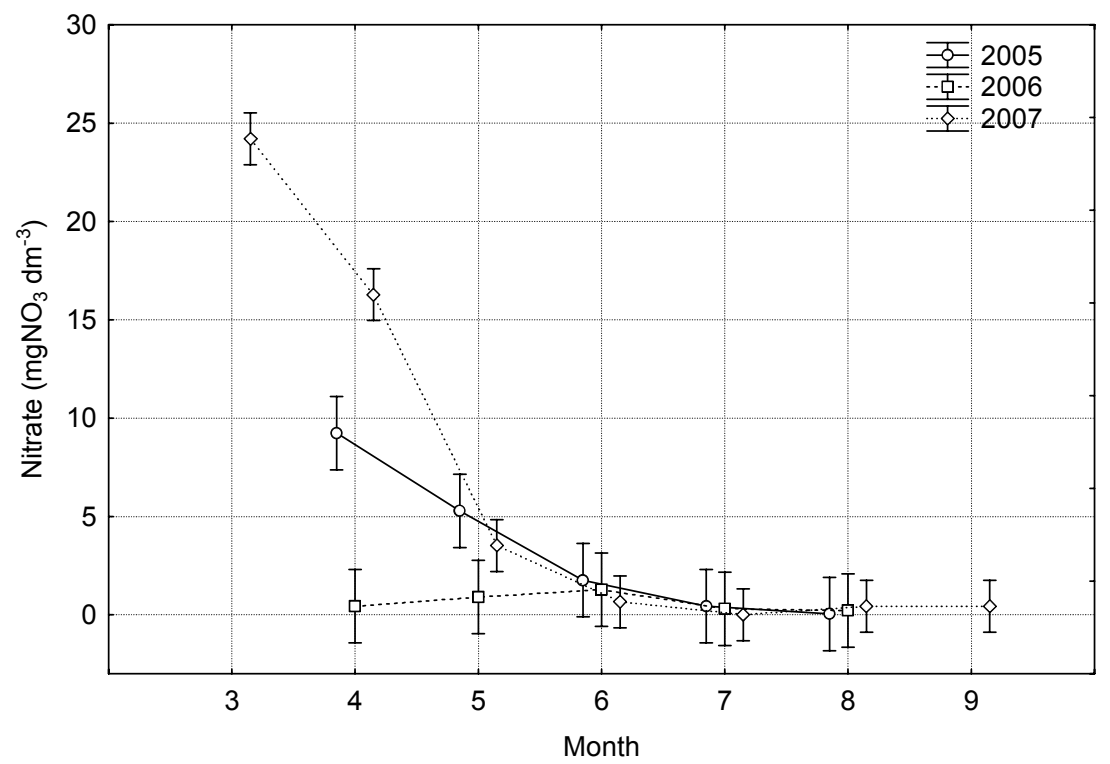

FIGURE 4. Nitrate concentrations $\left(\mathrm{mg} \mathrm{NO}_{3} \cdot \mathrm{dm}^{-3}\right)$ in the Niepruszewskie Lake in the 2005-2007

streams was poor, but the current results indicate a slight positive trend in nitrate reduction in surface waters throughout the studied period. In 2005 and 2007, differences between the annual mean nitrate concentrations indicated that $63 \%$ of sites showed a decreasing trend, while $38 \%$ exhibited an increasing tendency. Nevertheless, nitrate concentrations in the turbidities of the Niepruszewskie Lake were higher than during 1999-2002 (Zbierska et al. 2002). The most unfavorable year was 2006, where at $50 \%$ of the control sites average nitrate concentrations were higher than they had been in 2005, and in $25 \%$ of the sites the value exceeded $50 \mathrm{mg}$ $\mathrm{NO}_{3} \cdot \mathrm{dm}^{-3}$. This situation was probably due to weather conditions. After a cold, snowy winter, nitrate was leached from arable land to the surface waters with ground and surface water discharge. The current results confirm the findings of the DEFRA (2007c) study performed in England, which indicated that nitrate is lost from land mainly during winter and early spring when land is fully wet and drains flow. During the early part of winter, nitrate concentrations in the water were also relatively high, and most likely exceeded $50 \mathrm{mg} \mathrm{NO} \cdot \mathrm{dm}^{-3}$. It is at this time of year that water from the land dominates river flows and, in addition, fields are not covered by vegetation; this hypothesis is supported by the published results of Beckwith et al. (1998) and DEFRA (2007c). Mineral soil types dominate in the analyzed area, which also accelerated nitrate leaching from the fields into groundwater and surface water (Ławniczak and Zbierska 2007). The current results indicate that more effective measures must be implemented in the watershed to reduce nitrate pollution from agricultural sources but also phosphorus pollution from poorly 
functioning sewage systems. Diffuse N and $\mathrm{P}$ leaking from agricultural land and leaky sewage systems contributes to water quality deterioration by eutrophication (Lennox et al. 1997), which is particularly evident in Lake Niepruszewskie. The intense growth of planktonic algae and the high primary production of emergent macrophytes (Ławniczak 2009) signal the progressing process of eutrophication. The extremely eutrophic water quality of the reservoir confirmed its role as a nutrient sink, thus reducing pollution from the catchment. Advanced ecological awareness and appropriate measure must be implemented in the catchment of the Samica Stęszewska river, but also in Lake Niepruszewskie, in order to avoid further degradation and to improve water quality in surface waters.

\section{CONCLUSIONS}

1. Surface water quality in the upper part of the Samica Stęszewska River catchment was poor and, in almost all control sites, nitrate concentrations in the surface water ranged from 0.00 to $268.26 \mathrm{mg} \mathrm{NO} \cdot \mathrm{dm}^{-3}$ during 2003 and 2005.

2. Current results indicate a slight positive trend in nitrate reduction in surface waters throughout the studied period.

3. Increased $\mathrm{N}$ concentrations in the water during spring time indicate continuous high contribution of agriculture to water pollutions.

4. NVZ Action Programme is not effective at reducing nitrate pollution in the surface water. More precise methods have to be applied to improve water quality in the Samica Steszewska river catchment.

\section{ACKNOWLEDGEMENTS}

This study received financial support from the Ministry of Science and Informatisation, grant no 2 P06S 026 28. We would like to extend our thanks to Barbara Andrzejewska and Justyna Urbaniak for their help with laboratory analyses.

\section{REFERENCES}

BECKWITH C.P., COOPER J., SMITH K.A., SHEPHERD M.A. 1998: Nitrate leaching following application of organic manures to sandy soils in arable cropping. I. Effects of application time, manure type, overwinter crop cover and nitrification inhibition. Soil Use and Management. 14: 123-130.

CZARNECKA H. (ed.) 2005. Atlas podziału hydrograficznego Polski. [The Hydrological Atlas of Poland]. Wyd. IMGW.

DEFRA 2007a: The protection of waters against pollution from agriculture. Consultation on implementation of the Nitrates Directive. ADAS Report, England, 56.

DEFRA2007b: Nitrates in water - the current status in England (2006). Consultation on implementation of the Nitrates Directive. ADAS Report, England, 22.

DEFRA 2007c: Diffuse nitrate pollution from agriculture - strategies for reducing nitrate leaching. Consultation on implementation of the Nitrates Directive. ADAS Report, England, 52.

DZIENNIK URZĘDOWY WOJEWÓDZTWA WIELKOPOLSKIEGO $\mathrm{z}$ dnia 12 grudnia 2003 r., Nr 192, poz. 3568. [Jour- 
nal of Laws Wielkopolska Voivodeship from 12th December 2003 r., No 192, poz. 3568].

Rocznik... 2005: Rocznik statystyczny rolnictwaiobszarówwiejskich. [Yearbook of Agriculture and Rural Areas]. Zakł. Wyd. Stat. GUS, Warszawa, 485.

HUGHES A., CHILTON J., WILLIAMS, A. 2006: Investigating the Effectiveness of NVZ Action Programme Measures: Development of a Strategy for England. Report under Defra contract NIT18.

KUPIEC J. 2008: Ocena bilansu składników biogennych (NPK) jako podstawy monitoringu produkcji rolnej $\mathrm{w}$ aspekcie ochrony środowiska. [Estimation of nutrients balance (NPK) as a basis of monitoring in agricultural production in environmental protection aspect. $\mathrm{PhD}$ thesis]. Praca doktorska. Uniwersytet Przyrodniczy w Poznaniu, Poznań, 211.

KUPIEC J., ŁAWNICZAK A.E., ZBIERSKA J. 2008: Action reducing the outflow of nitrates from agricultural sources to waters on the nitrates vulnerable zone in the catchment of Samica Stęszewska river. Ann. Warsaw Univ. of Life Sci. - SGGW, Land Reclam [in press].

KONDRACKI J. 2001: Geografia regionalna Polski. [Regional geography of Poland]. Wyd. Nauk PWN. Warszawa, 441.

LENNOX S.D., FOY R.H., SMITH R.V., JORDAN C. 1997: Estimation the contribution of agriculture to the phosphorus load in surface water. [In:] Tunney H., Carton O., Brooks P., Johnston A. (Eds.). Phosphorus loss from soil to water. $\mathrm{CAB}$ International, Wallingford, 55-75.

ŁAWNICZAK A.E., ZBIERSKA J. 2007: Effect of system management in the buffer zone of the lake on groundwater quality. Fragmenta Agronomica, 3 (95): 283-291 [Engl. summ.].

ŁAWNICZAK A.E. 2008: The role of emergent macrophytes in nutrient cycling in Lake Niepruszewskie (western Poland). Oceanological and Hydrobiological Studies [in press].
ROZPORZĄDZENIE... 2002a: Rozporządzenie Ministra Środowiska $\mathrm{z}$ dnia 23 grudnia 2002 r. w sprawie kryteriów wyznaczania wód wrażliwych na zanieczyszczenie związkami azotu ze źródeł rolniczych. DzU Nr 241, poz. 2093. [Ministry of the Environment Ordinance dated 23 Dec. 2002 on determining waters sensitive to nitrogen contamination from agricultural sources. Act Reg. 2002. No 241, it. 2093].

ROZPORZA_DZENIE... 2004: Rozporządzenie Ministra Środowiska $\mathrm{z}$ dnia 11 lutego 2004 roku w sprawie klasyfikacji dla prezentowania stanu wód powierzchniowych i podziemnych, sposobu prowadzenia monitoringu oraz sposobu interpretacji wyników i prezentacji stanu tych wód. DzU Nr 32, poz. 284. [Ministry of the Environment Ordinance dated 11 Feb. 2004 on classification for presentation of surface and groundwater quality, methods of conducting the monitoring management and methods of interpretation and presentation water status. Act Reg. 2004. No 32, it. 284].

ROZPORZA_DZENIE... 2002b: Rozporządzenie Ministra Środowiska $\mathrm{z}$ dnia 23 grudnia 2002 r. sprawie szczegółowych wymagań, jakim powinny odpowiadać programy działań mających na celu ograniczenie odpływu azotu ze źródeł rolniczych. DzU z 2003 r. Nr 4, poz. 44. [Ministry of the Environment Ordinance dated 23 Dec. 2002 on detailed requirements for limiting nitrogen run-off from agricultural sources oriented programmes. Act Reg. 2003. No 4, it. 44].

REPORT... 2007: Report from the commission to the council and the European Parliament on implementation of Council Directive 91/676/EEC concerning the protection of waters against pollution caused by nitrates from agricultural sources for the period 2000 -2003. Commission of The European Communities, Brussels, 11. 
ZBIERSKA J., MURAT-BŁAŻEJEWSKA S., SZOSZKIEWICZ K., ŁAWNICZAK A. 2002: Bilans biogenów w agroekosystemach Wielkopolski w aspekcie ochrony jakości wód na przykładzie zlewni Samicy Stęszewskiej. [The nutrients balance in Wielkopolska agro-ecosystems with respect to water quality protection using the Samica Stęszewska river watershed as example]. Wyd. AR Poznań, 133 [Engl. summ.].

Streszczenie: Zmiany stęzenia zwiqzków biogennych $w$ wodach wrażliwych na zanieczyszczenia zwiqzkami azotu ze źródet rolniczych $w$ zlewni rzeki Samicy Stęszewskiej. Celem pracy była ocena jakości wód powierzchniowych w pierwszym okresie wdrażania działań ograniczających zanieczyszczenie wód azotanami ze źródeł rolniczych oraz ocena skuteczności podejmowanych działań ochronnych na obszarze szczególnie narażonym na zanieczyszczenie azotanami (OSN). Badania były prowadzone w górnej części zlewni rzeki Samicy Stęszewskiej, położonej na terenie Wielkopolski. Badania prowadzono w latach 2005-2007 w ramach projektu nr 2 PO6S 026 28, finansowanego przez Ministerstwa Nauki i Informatyzacji. Wodę analizowano w 9 punktach kontrolnych (na dopływie i odpływie rzeki Samicy Stęszewskiej z Jeziora Niepruszewskiego, 6 dopływach do Jeziora Niepruszewskiego i w samym akwenie) w odstępach comiesięcznych, oznaczając spektrofotometrycznie stężenie azotanów, fosforu ogólnego i chlorofilu $a$ według standardowych metod. Jakość wód powierzchniowych prawie we wszystkich punktach badawczych była zła i odpowiadała, ze względu na wysokie stężenia azotanów, IV i V klasie jakości, okresowo przekraczającymi wielkość progową określoną w Dyrektywie Azotanowej. Jedynie wody Samicy Stęszewskiej na odpływie z Jeziora Niepruszewskiego odpowiadały I, II i III klasie jakości. Również wody jeziora charakteryzowały się wysokimi stężeniami związków biogennych, a częste i intensywne zakwity wody świadczą o wysokim stopniu zeutrofizowania wód i postępującej degradacji akwenu. Wyniki badań jakości wód na badanym obszarze wskazują na niewłaściwe gospodarowanie biogenami w zlewni rzeki Samicy Stęszewskiej i mimo podejmowanych działań ochronnych wciąż duży udział rolnictwa w eutrofizacji wód.

MS. received November 5, 2008

\author{
Authors' address: \\ Agnieszka E. Ławniczak \\ email: lawnic@up.poznan.pl \\ tel. +48618466515 \\ Janina Zbierska \\ email: jzbier@up.poznan.pl \\ Jerzy Kupiec \\ email: jkupiec@up.poznan.pl \\ Katedra Ekologii i Ochrony Środowiska \\ Uniwersytet Przyrodniczy w Poznaniu \\ ul. Piątkowska 94C, 60-649 Poznań, \\ Poland
}

